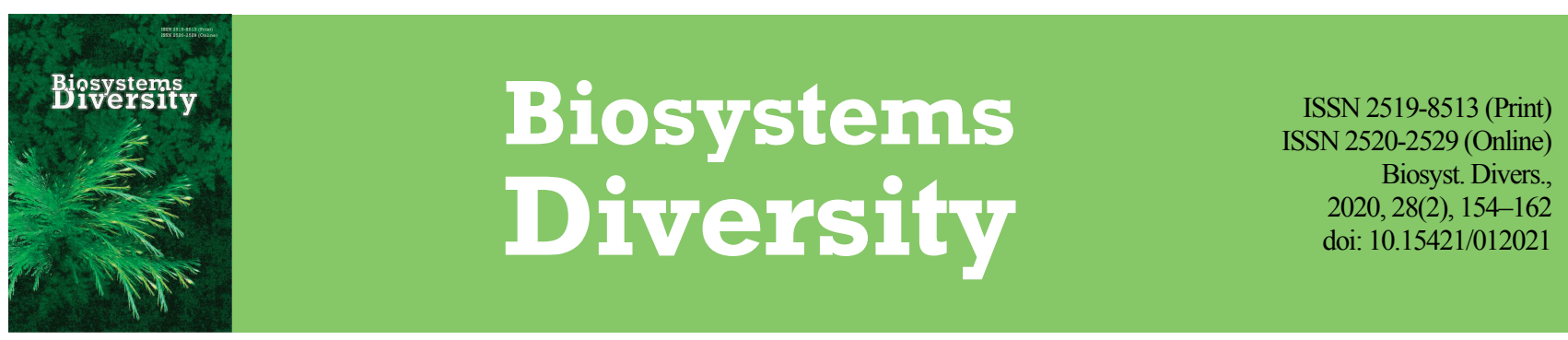

\title{
Population systems of Eurasian water frogs (Pelophylax) in the south of Ukraine
}

\author{
N. M. Suriadna*, G. I. Mykytynets**, M. Pupiņš̌**, V. Y. Gasso**** \\ *Melitopol Insitute of Ecology and Social Technologies of University "Ukraine”, Melitopol, Ukraine \\ **Pryazovsky National Nature Park, Melitopol, Ukraine \\ ***Institute of Life Sciences and Technologies, Daugavpils University, Daugvapils, Latvia \\ ****Oles Honchar Dnipro National University, Dnipro, Ukraine
}

Article info

Received 20.04.2020

Received in revised form 27.05.2020

Accepted 30.05.2020

Melitopol Insitute of Ecology and Social Technologies of University

"Ukraine", Interkulturna st,. 380,

Melitopol, 72316, Ukraine.

Tel.: +38-067-613-67-09.

E-mail: suriadna@gmail.com

Pryazovsky National Nature Park

Ivan Bohun st., 46

Melitopol, 72300, Ukraine.

Tel.: + 38-097-044-07-38

E-mail:skolot.gala@gmail.com

Institute of Life Sciences

and Technologies, Daugavpils

University, Parades st., $1 A$,

Daugvapils, LV5401, Latvia.

E-mail:mihails.pupins@gmail.com

Oles Honchar Dnipro National

University, Gagarin av., 72,

Dnipro, 49010, Ukraine.

Tel.: +38-097-302-56-83.

E-mail:viktor.gasso@gmail.com

\section{Introduction}

The problem of natural cross-species hybridization has reached a new level and nowadays is considered as one of the driving forces of evolution along with the traditional processes of speciation. It is well known that the reproductive barrier between species leads to the hybrid sterility and emergence of non-viable offspring. Nevertheless, among vertebrate species complexes there are ones that overcome this barrier, in particular by hybridogenesis. It may represent the first stage of hybrid speciation, separation from parental species and the gaining of an independent hybrid taxon status. The Eurasian water frogs of the genus Pelophylax (Fitzinger, 1843), which spend much time in aquatic habitat and also known as green frogs, play a special role the hybrid speciation. In Ukraine, it is represented by two parent species: Pelophylax ridibundus (Pallas, 1771) and $P$. lessonae (Camerano, 1882) and the cross-species hybrid $P$. esculentus (Linnaeus, 1758). This group of European frogs $-P$. esculentus complex, forms mixed and pure population systems that have a generally accepted classification and are indicated in accordance with the Latin names of taxa $(\mathrm{R}-$ ridibundus, $\mathrm{L}$ - lessonae, $\mathrm{E}$ - esculentus). Hybridogenous $P$. esculentus with the RL genome usually removes one parental genome from its germ line, sympatrically coexists and crosses with one or both parental species $P$. lessonae (LL genome) or $P$. ridibundus (RR genome) in mixed popula- tion systems LE, RE REL. Fully hybrid (EE) and parental species (RR, LL, RL) populations also exist.

Population genome organization, specifics of population genetic processes and their environmental and evolutionary consequences directly depend on the type of population system. Therefore, study of formation and distribution of the population systems, which provide own reproduction and sustainable existence, like $P$. esculentus complex, is of high priority for science. This complex is generally acknowledged to be a model for the study of modern processes of hybrid speciation (Plötner, 2005; Avise, 2008; Borkin et al., 2008). Hybridization processes, overcoming the sterility of hybrids, cross-species recombination, non-Mendelian inheritance, polyploidy and the population systems diversity are actively studied (Mikulíček \& Kotlík, 2001; Rybacki \& Berger, 2001; Tecker et al., 2017).

The expansion of population systems within their area of distribution has a certain specificity. In the Eastern European part of its range, green frogs form both pure parent (mainly RR) and mixed (mainly RE) systems, including triploid and unisexual hybrids (Lada et al., 2009; Suryadna 2010; Litvinchuk et al., 2015; Shabanov et al., 2017). In the Western European part of the range, LE-type systems are more common (Plötner, 2005), which is explained by the area of distribution of $P$. lessonae and P. esculentus. A high percentage of triploids have been found there in all mixed populations (Rybacki \& Berger, 2001). RL and EE systems are rare in the 
Eastern European part but are found in Ukraine, Belarus and Russia (Lada et al., 1995; Borkin et al., 2002; Svinin et al., 2013). REL are rare throughout the frogs range and, with the exception of the East part, are confirmed with a low percentage in the Czech Republic, Poland, Hungary (Herczeg et al., 2016), Romania, Germany (Plötner, 2005), Slovakia (Mikulíček et al., 2015), the Netherlands, and Serbia (Hoffmann et al., 2015). To a lesser extent RE systems were also found in Germany, Denmark, Poland, Hungary and Czech Republic (Plötner, 2005; Dolezalkovâ-Kastankovâ et al., 2018).

Pure hybrid EE systems of the Western European part of the range are common in France, Sweden (Ebendal, 1979; Christiansen et al., 2010), Germany (Günther, 1975; Tecker et al., 2017), Denmark (Christiansen et al., 2005), Latvia, the Netherlands, Slovakia (Mikulíček \& Kothk, 2001), Poland, and the Czech Republic (Berger, 1983; Berger \& Berger, 1994; Pruvost et al., 2013). The triploid-free EE system is reliably found in Southern Switzerland, where hybrid amphigamy is considered, and polyploidy is assumed to be not the only evolutionary path for the reproductive independence of hybrids (Dubey et al., 2019). Thus, P. esculentus has different origins and consists of numerous genetic lines (Hoffmann et al., 2015); both clonal and recombinant genomes can be transmitted that depends on the specifics of the population system (Doležálková et al., 2016; Dubey et al., 2019).

The territory of Southern Ukraine, just like the entire Steppe Zone with diverse physiographic complexes and landscapes, is of particular interest. The ecotone character of the range, powerful anthropogenic impact and transformation of biotopes have an effect on the amphibian populations functioning. To date, significant data have been accumulated on the expansion of water (green) frogs population systems, including their ecological and genetic characteristics and the southern range of $P$. esculentus and $P$. lessonae. Found populations have local limited distribution that may condition their specific relict value of unique genetic diversity, probably, conserved ancestral $P$. lessonae genome.

The specifics of the genetic structure, direction of gene flows and ploidy in the south Ukrainian population systems are the main prospects for further research. The aim of the study is to elucidate the specifics of the Eurasian water frog population systems distribution, the ratio of taxa, sexual structure, species number, ploidy and the nature of their biotopes. Modern natural and climatic changes and powerful anthropogenic impact with biotope transformation in the south of Ukraine have made amphibians vulnerable. However, existing successful populations have adapted to those conditions and are able to evolve due to complex mechanisms of microevolution that are still not understood well. Our research is especially important for conservation of the unique population systems of green frogs in the south of Ukraine.

\section{Material and methods}

The study was carried out according to modern requirements in the treatment of experimental animals. The European Convention for the Protection of Vertebrate Animals used for Experimental and other Scientific Purposes (Strasbourg, 03.18.1986) and the Law of Ukraine "On the Pro- tection of Animals from Cruel Treatment" (No. 3447-IV of 02.21.2006) have been adhered to. The Expert Commission on Bioethics of the University "Ukraine" has confirmed the compliance with bioethical standards.

The study has been conducted over the past 25 years. The total number of studied animals is 4426 individuals from 198 populations. Among them, 3674 individuals are from the south of Ukraine (130 populations). 752 individuals (68 populations) were collected from adjacent territories outside the south of Ukraine, including several sites in Romania and the Caucasus. In this work we used materials from the collections of the The National Museum of Natural History, NAS of Ukraine (Suriadna \& Pysanets, 2010; Suriadna \& Mykytynets, 2019). The total number of male, female and juvenile individuals is presented in the Table 1. The commonly used classification of population systems corresponds to the Latin names of taxa: $\mathrm{R}$ - ridibundus, $\mathrm{L}$ - lessonae, $\mathrm{E}$ - esculentus) (Uzzel \& Berger, 1975).

We used morphological, genetic and environmental diagnostic methods for identification of the European water frog species. Morphological analysis $(\mathrm{n}=2600)$ was carried out for the 36 external characteristics (23 morphological metric indices, 46 variants of 13 qualitative ones, and weight) by which water frogs are traditionally tested. Snout-vent length (SVL) and weight confirm the species status of studied animals. According to our data $P$. ridibundus is the largest frog $(\mathrm{SVL}=74.2 \pm 0.4 \mathrm{~mm} ; \mathrm{n}=$ 1525), $P$. lessonae is the smallest one $(\mathrm{SVL}=56.5 \pm 3.9 \mathrm{~mm} ; \mathrm{n}=40)$, and $P$. esculentus has an intermediate size $(\mathrm{SVL}=64.8 \pm 0.6 \mathrm{~mm} ; \mathrm{n}=301)$. The average body weight demonstrates the same results: $P$. ridibundus $41.5 \pm 0.7 \mathrm{~g}(\mathrm{n}=1614)$, P. esculentus $-20.8 \pm 0.7 \mathrm{~g}(\mathrm{n}=413)$, P. lessonae$16.6 \pm 2.0 \mathrm{~g}(\mathrm{n}=40)$. Discriminant analysis of the hind limbs parameters (longitudo femoris, longitudo tibiae, longitudo primus digitus, longitudo callus internus, and altitudo callus internus) showed three separate groups that corresponds to the species status of the water frog complex (Fig. 1).

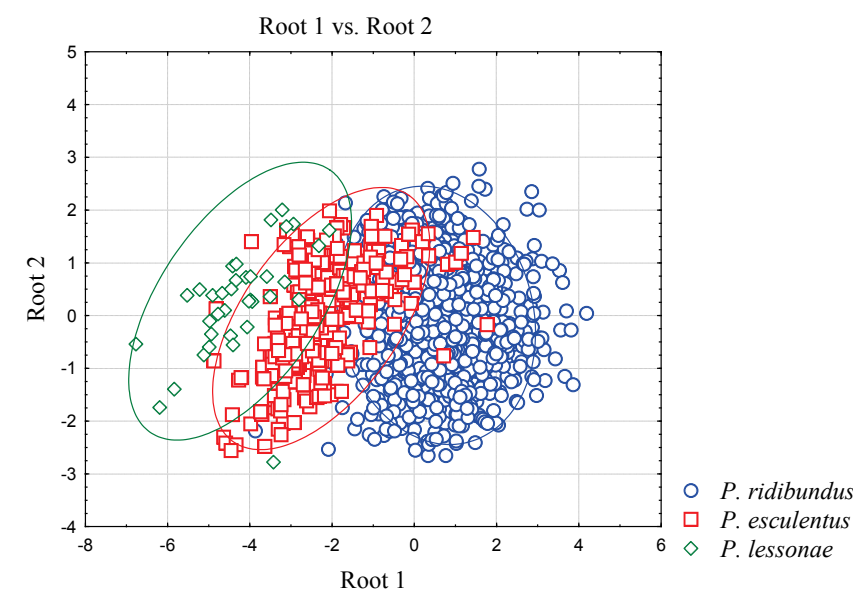

Fig. 1. Discriminant analysis of the hind limbs parameters (longitudo femoris, longitudo tibiae, longitudo primus digitus,

longitudo callus internus, and altitudo callus internus) of Eurasian water frogs Pelophylax esculentus complex $(\mathrm{n}=2600)$

Table 1

Population systems types of water frogs Pelophylax esculentus complex in the south of Ukraine with quantitative characteristics

\begin{tabular}{|c|c|c|c|c|c|c|c|}
\hline $\begin{array}{c}\text { Population systems } \\
\text { (percentage of polyploidy) }\end{array}$ & Total number (n) & Males & Females & Juveniles & $\begin{array}{c}\text { Percentage } \\
\text { of individuals, } \% \\
\end{array}$ & $\begin{array}{c}\text { Total number } \\
\text { of population systems (n) }\end{array}$ & $\begin{array}{c}\text { Percentage } \\
\text { of population systems, } \%\end{array}$ \\
\hline RR & 2442 & 998 & 830 & 114 & 100.00 & 99 & 76.2 \\
\hline P. ridibundus & 2441 & 997 & 830 & 114 & 99.96 & 98 & 75.4 \\
\hline 4n P. ridibundus ( $1.0 \%$ of $\mathrm{RR})$ & 1 & 1 & 0 & 0 & 0.04 & 1 & 0.8 \\
\hline $\mathrm{RE}$ & 1466 & 465 & 396 & 175 & 100.00 & 26 & 20.0 \\
\hline P.ridibundus & 1160 & 322 & 375 & 92 & 79.10 & \multirow{2}{*}{24} & \multirow{2}{*}{18.5} \\
\hline P. esculentus & 303 & 142 & 19 & 83 & 20.70 & & \\
\hline 3n P. esculentus (7.7\% of RE) & 3 & 1 & 2 & 0 & 0.20 & 2 & 1.5 \\
\hline REL & 418 & 168 & 122 & 65 & 100.00 & 5 & 3.8 \\
\hline P. ridibundus & 257 & 100 & 100 & 18 & 61.50 & \multirow{3}{*}{5} & \multirow{3}{*}{3.8} \\
\hline P. esculentus & 120 & 64 & 12 & 35 & 28.70 & & \\
\hline P. lessonae & 41 & 4 & 10 & 12 & 9.80 & & \\
\hline Total: & 4326 & 2264 & 1866 & 594 & 100.00 & 130 & 100.0 \\
\hline
\end{tabular}


The main qualitative diagnostic characters confirmed the taxonomic status also. $P$. ridibundus is the most polymorphic, predominantly dark and has faint unsaturated colours. $P$. esculentus has light brown $(26.0 \%)$ and green $(38.0 \%)$ tinctures. $P$. lessonae of bright green and brown tints is the least variable in colouration. All studied $P$. esculentus have a dorsomedial stripe. This attribute is less peculiar to P. lessonae $(95.0 \%)$ and P. ridibundus (72.0\%). P. lessonae and $P$. esculentus are mainly finely spotted ( $52.5 \%$ and $62.0 \%$, respectively). $P$. ridibundus is usually characterized by large dark spots (58.0\%). P. lessonae males have resonators of almost white colour $(89.0 \%)$. The resonators of $P$. esculentus are of dirty white $(71.0 \%)$ and those of $P$. ridibundus are of dark grey $(87.0 \%)$. P. lessonae and $P$. esculentus have typical bright yellow contrasting tints of the flanks and upper part of thighs in the vast majority of cases.

In total, 47 individuals were tested for nuclear DNA analysis ( 8 P. ridibundus, 4 P. lessonae and 22 P. esculentus). The technique is described in details previously (Borkin et al., 2001). The obtained results confirm the water frogs identity, $P$. ridibundus has $16.2 \pm 0.1 \mathrm{pg}$ of nuclear DNA (min-max: 16.1-16.3) P. lessonae - $13.9 \pm 0.1$ pg (13.8-14.1) and P. esculentus $-15.2 \pm 0.1$ pg (14.9-15.6). Ploidy (general / partial) was determined by chromosome analysis. The technique and morphology were described by us earlier (Suryadna, 2003; Suryadnaya, 2004). 2363 karyoplates and 230 metaphase plates of 577 frogs were analyzed in total.

Standard field research methods (Pysanets \& Suriadna, 2007) were used. About 200 field trips and long-time expeditions were carried out in total. Mapping of the sites was carried out using ArcGIS (www.arcgis.com). We used the National Classification of Biotopes with a brief description by their corresponding codes (Kuzemko et al., 2018). Climatic data (air, water and soil temperatures, $\mathrm{pH}$, and salinity) were determined with standard alcohol thermometers and AZ-86021 oximeter/pH meter.

\section{Results}

Three population systems RR, RE and REL were identified and confirmed in the south of Ukraine. Four types of systems, such as LL, EE, RL and $\mathrm{LE}$, are distributed northward within the main range of $P$. lessonae and P. esculentus distribution (Table 1, Fig. 2).
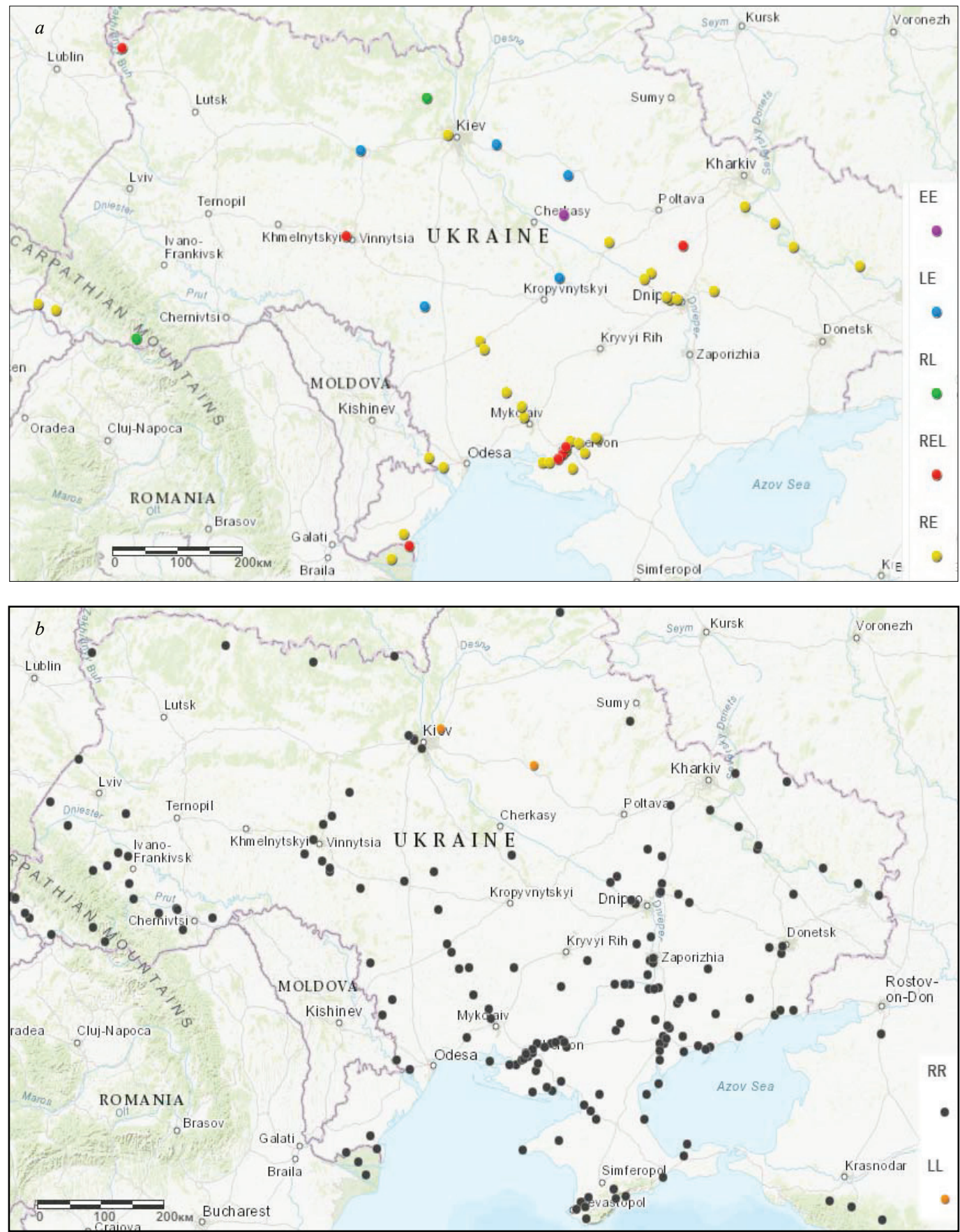

Fig. 2. Locations of the population systems of Eurasian water frogs Pelophylax esculentus complex: $a$-EE, LE, RL, RE, REL; $b-\mathrm{RR}, \mathrm{LL}$ 
Populations of $P$. ridibundus (RR). Ninety-nine "pure" RR populations out of 130 were determined, representing $76.2 \%$ (Table 1, Fig. 2, 3). They are mainly distributed in the southeastern part (Fig. 3). Such populations predominate in other parts of the range (Fig. 2). Outside of the south, 51 populations $(75.0 \%)$ were identified of the 68 .

The tetraploid specimen of $P$. ridibundus $(4 \mathrm{n}=52)$ was found for the first time in the isolated population of Velyki Kuchuhury island, National Park 'Velykyi Luh', Kakhovske reservoir, Zaporizhzhia region $\left(47.5559^{\circ} \mathrm{N}\right.$, $35.2140^{\circ} \mathrm{E}$, Fig. 3). It represents $1.0 \%$ among the RR population systems of the Southern Ukraine and $0.8 \%$ of the total analyzed material (Table 1).

The ratio of females and males is traditional $1: 1(1.07: 0.8$, , Table 1$)$. The number averages 5-35 indiv. $/ 100 \mathrm{~m}$. The largest population of P. ridibundus was found in the floodplains of the Danube River (Stentsivsko-Zhebriyanovski Plavni, Danube Biosphere Reserve, Odesa region, $45.5683^{\circ} \mathrm{N}, 29.4812^{\circ} \mathrm{E}$ ) in $2000-2001$, where the $100 \times 100 \mathrm{~m}$ section held more than 1000 adult frogs and more than 200 individuals were observed along $20 \mathrm{~m}$ of the shoreline. Unfortunately, nowadays the population has decreased in number significantly.

P. ridibundus occupies permanent, temporary and coastal continental freshwater bodies and streams (B1-B4). It also lives in the floodplain willow and poplar forests, humid forests with oak, elm, alder and ash (D1.6-1.7). The species is constantly found in synanthropic biotopes (C4). Hydrochemical and hydrophysical indices allow $P$. ridibundus to live at an average air temperature of $18.9^{\circ} \mathrm{C}$ (min-max: 7.0-27.0), $18.4{ }^{\circ} \mathrm{C}$ of water (5.2-30.0), 2.9\%o of salinity (0.5-6.8) and pH 8.4 (6.1-10.0).

Populations of $P$. ridibundus $-P$. esculentus (RE). Among the semiclonal mixed population systems, the most numerous is the RE-type. This system takes $20.0 \%$ for the steppe zone and $8.8 \%$ for another territory (Fig. 2, Table 1). Geographically concentrated in the floodplains of the large rivers Danube, Dnister, Ingul, Ingulets, Pivdennyi Buh, Dnipro, Siverskyi Donets with slow flowing or standing water (Fig. 2, 4). It can also be found along the banks of large rivers with a fast flow along with $P$. ridibundus (for example, the Pivdennyi Buh River, near vil. Kuripchyne, RLP "Hranitno-Stepove Pobuzhzhia", NNP "Buzkyi Hard", 47.9965N, $\left.31.0045^{\circ} \mathrm{E}\right)$.
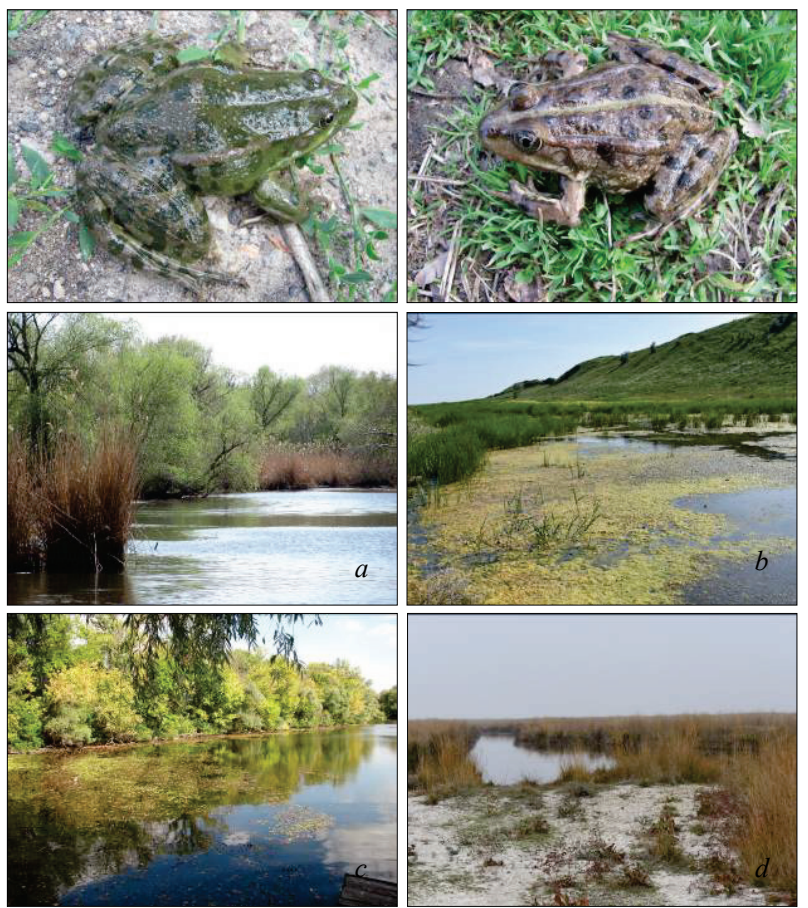

Fig. 3. Populations of $P$. ridibundus $-\mathrm{RR}$ and typical biotopes of the Southern Ukraine: $a$ - Velyki Kuchuhury island, Kakhovske Reservoir, Zaporizhzhia region; $b$ - coast of Molochnyi Liman, vil. Ohrymivka,

Zaporizhzhia region; $c$-Dnipro River, Khortytsia Island,

Zaporizhzhia region; $d$-Biriuchyi Ostriv spit, Kherson region

In all representative samples, the parental species $P$. ridibundus predominates numerically. $P$. esculentus accounts for $20.7 \%$. P. esculentus prevails only in the populations of the outskirts of vil. Pokrovka, Kinburs- ka spit, "Biloberezhzhya Sviatoslava" National Park, RLP "Kinburska Kosa" Regional Landscape Park, Mykolaivska region $\left(46.4811^{\circ} \mathrm{N}\right.$, $31.7020^{\circ} \mathrm{E}$ ) and outskirts of vil. Gaidary, Iskiv Stavok, Zmiivskyi district, Kharkiv region, (at the border with the forest-steppe zone $-49.6250^{\circ} \mathrm{N}$, $\left.36.2861^{\circ} \mathrm{E}\right)$. Hemiclonal population systems with the presence of triploidy $(3 n=39)$ account for $7.7 \%$ of the RE systems in the south of Ukraine (Table 1).
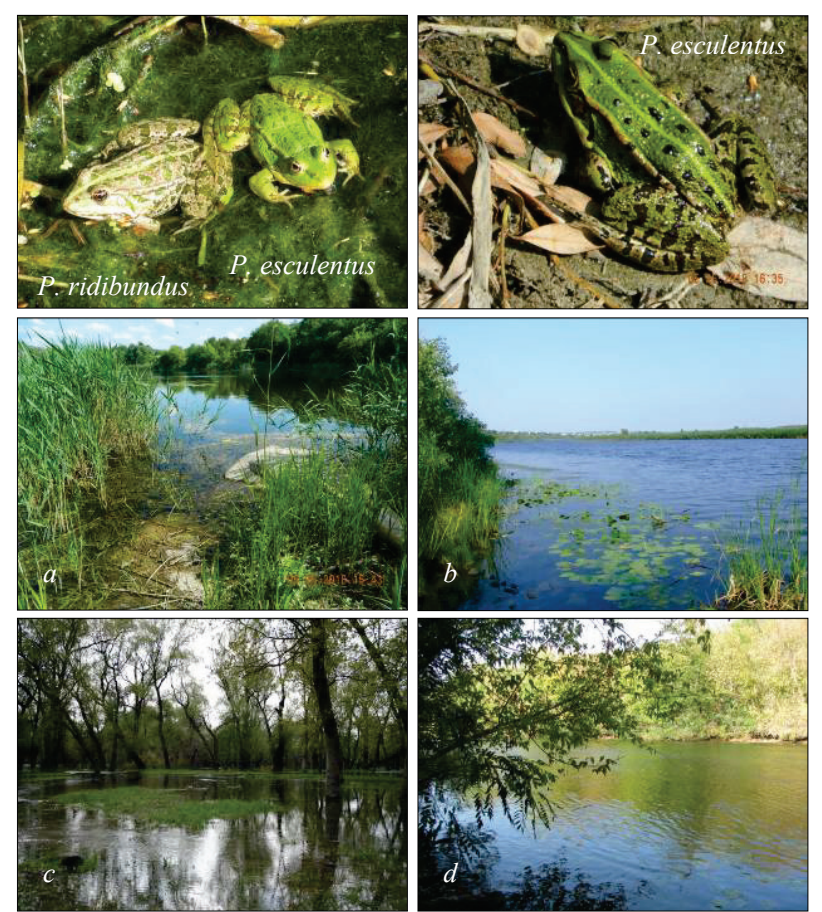

Fig. 4. P. ridibundus and $P$. esculentus of a hemiclonal RE-type population system of Southern Ukraine and typical biotopes: $a$-Pivdennyi Buh River, vil. Kuripchyne, Mykolaiv region; $b$ - Ingulets River, vil. Daryivka, Belozerskyi district, Kherson region;

$c$-Dnister River, vil. Troitske, Odesa region; $d$-Dnipro River, vil. Krynky, Oleshkivskyi district, Kherson region

The sex ratio is $1.0 \delta^{\lambda}: 1.0$ in the population of $P$. ridibundus. Males predominate $\left(1.00^{1}: 0.1\right.$ ) among $P$. esculentus. Females are found on the border between steppe and the forest-steppe zones. Almost all males have abnormalities of sexual features, including the absence of resonators in adults, various anomalies of the testes (our unpublished data). The amphibian abundance in studied RE-system is $1-9$ indiv. $/ 100 \mathrm{~m}$ of the shoreline.

The water frogs prefer water bodies of slow flow. P. esculentus inhabits the following biotopes: permanent stagnant freshwater bodies with macrophytic vegetation (B1.1); areas of permanent stagnant water bodies without higher aquatic vegetation (B1.3 - rarely) temporary freshwater bodies (B2.1); small stagnant and temporary water bodies with macrophytic vegetation (B2.1.3); slow-flow mesotrophic and eutrophic water bodies (B3.2.2); coastal biotopes of stagnant water bodies and streams of plains and low mountains (B4.1); coastal cereal grass thickets along streams (B4.1.2); tall grass edge nitrophilic biotopes of lowland rivers (B4.1.6). Among the forest biotopes, D1.6.-1.7 is for RR. The optimal hydrochemical and hydrophysical indicators of this population system locations are: air temperature $-18.5^{\circ} \mathrm{C}(\min -\max : 8.0-26.5)$, water $18.4{ }^{\circ} \mathrm{C}(10.0-28.0)$, salinity $-2.0 \%$ (0.1-7.6) and $\mathrm{pH} 8.5(5.2-10.4)$.

Populations of $P$. ridibundus $-P$. esculentus $-P$. lessonae (REL). Only five REL population systems were found. They are concentrated in the lower Danube and Dnipro and make up 3.8\% for the Southern Ukraine (Table 1, Fig. 5). Two populations (2.9\%) were found for another studied area. To the north, on the steppe / forest-steppe border, such a system was found in the "Ruskyi Orchyk" tract (the border between Poltava and Kharkiv regions, $49.1669^{\circ} \mathrm{N}, 35.0375^{\circ} \mathrm{E}$ ) (Fig. 6). The species ratio there was: $P$. ridibundus $-61.5 \%$, P. esculentus $-28.7 \%$, P. lessonae $-9.8 \%$ (Table 1). Triploidy was not detected, but individuals of $P$. esculentus with a mosaic of chromosomes are found. The sexual structure of REL for the south is ambiguous: $P$. ridibundus $-1.0{ }^{1}: 1.0$; $P$. esculentus - 
$1.0{ }^{\lambda}: 0.2$ 오 (males predominate), but $P$. lessonae $-0.4 \delta^{\lambda}: 1.0$ 우 (females prevail). We should emphasize that the number of studied $P$. lessonae is insignificant; therefore, the data need to be clarified.

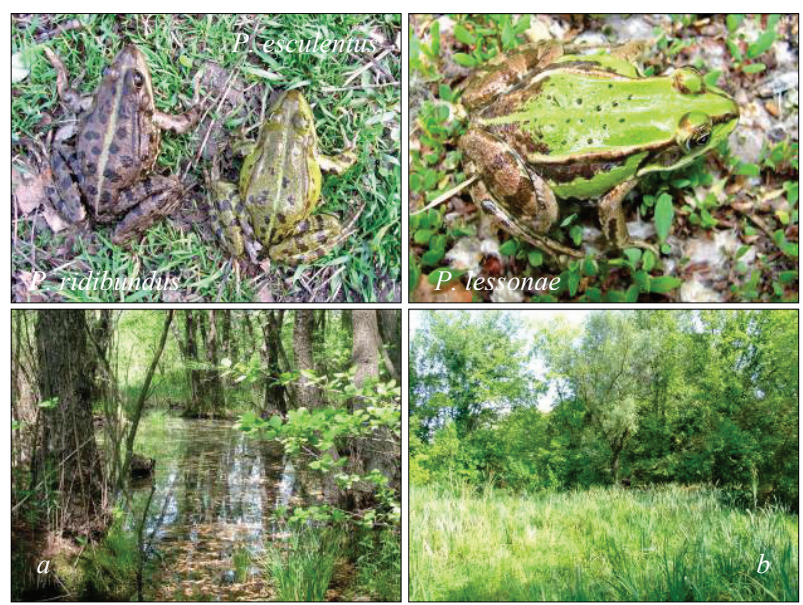

Fig. 5. P. ridibundus, $P$. esculentus, $P$. lessonae of the REL-type population system in the south of Ukraine and their typical biotopes:

$a-$ vil. Pravi Solontsi, Oleshkivskyi district, Kherson region; $b$-vil. Antonivka, Kherson region

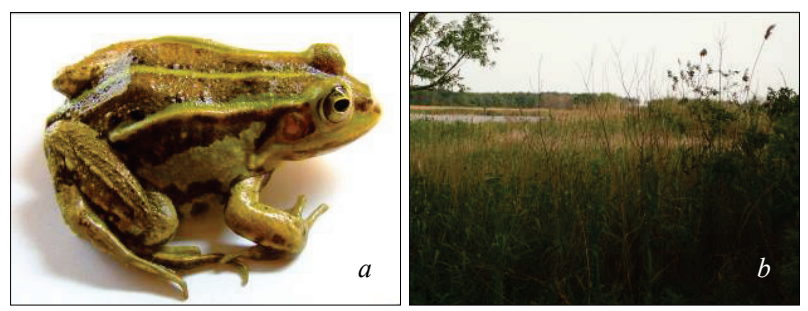

Fig. 6. P. lessonae of the REL-type population system: $a-P$. lessonae; $b-$ River Oril, "Ruskiy Orchik" tract, vil. Zarichne, Zachepylivskyi district, Kharkiv region

The number of $P$. lessonae was extremely low and amounts to $1-$ 2 frogs in separate local populations. We found the REL system exclusively in floodplain forest biotopes (D1.6.1), periodically humid forests with a predominance of oak or elm species (D1.6.2). The air and water temperatures were $9.0-17.0^{\circ} \mathrm{C}$ both, $\mathrm{pH} 7.5$ with weak water mineralization of $2.6 \%$.

Population systems of adjacent territories. Four population systems were not found in Southern Ukraine and occurred in the north of the main range of $P$. lessonae and $P$. esculentus (Fig. 2). These populations were $P$. lessonae (LL), parental RL, hemiclonal LE and a single system that consists only of EE-type hybrids. The percentage of two LL populations with $P$. lessonae and two mixed with parental RL species was $2.9 \%$ each only. The number of individuals in these populations was critically low; gender was not determined. Among the four populations of hemiclonal LE (5.9\%), the closest to the Steppe Zone was the population system of the "Chornyi Lis" tract near vil. Znamenka Kropyvnýtskyi region ( $\left.48.7745^{\circ} \mathrm{N}, 32.5456^{\circ} \mathrm{E}\right)$. Females of $P$. esculentus predominated in the population. The ratio of species was close to 1 . The percentage of $P$. lessonae was $54.1 \%$ and $P$. esculentus $-45.9 \%$. Mention should be made of one revealed hybridogenic system of $P$. esculentus (EE). This rather rare grouping for this region amounts to only $1.5 \%(\mathrm{n}=68)$. The population was in the outskirts of vil. Lyashchivka, Chornobaivskyi district, Cherkasy region $\left(49.5317^{\circ} \mathrm{N}, 32.6772^{\circ} \mathrm{E}\right)$. Males predominated more than twice in the population $-2.5 \delta^{\lambda}: 1.0$. The largest variety of population systems in the south of Ukraine occurs in nature conservation areas.

\section{Discussion}

To date, a number of works have been published on the Eurasian green frogs' population systems identification and distribution within their range, including the territory of Ukraine (Borkin et al., 2008; Lada et al.,
2009; Litvinchuk et al., 2015; Shabanov et al., 2017). According to literature data, pure and mixed populations of parent species (RR, LL and RL), hemiclonal mixed populations (RE, LE and REL), and the EE-type hybrid system are distinguished. In different parts of the range, they have a certain percentage, genetic structure and ploidy, sexual structure and other specific population characteristics. The study of the genetic structure allows determining the complex mechanisms of genome elimination of one of the parent species or the possible recombination of genetic material and a number of environmental and evolutionary consequences formed due to these complex processes (Mikulíček et al., 2015; Herczeg et al., 2016; Dubey et al., 2019).

According to our data, in the south of Ukraine, P. ridibundus (RR) populations and mixed hemiclonal systems (RE and REL) with different ploidy, number and specific sexual structure are the most common. Four systems are distributed within adjacent territories, in the northern, northwestern and north-eastern parts in particular. These are pure $P$. lessonae (LL), parental species (RL), hemiclonal (LE) and hybrid (EE) systems. The south of Ukraine is approximately the central part of the entire range of $P$. ridibundus and may be considered as the south-eastern edge of $P$. esculentus and $P$. lessonae ranges. Our results complement and reliably confirm our previous studies and literature data (Mikitinez \& Suryadna, 2007; Borkin et al., 2008; Suryadna \& Mikitinez, 2008; Mezhzherin et al., 2010).

Distribution of population systems. First, the presence, nature of distribution, and percentage of the population systems of water frogs should be discussed. Relevant regional studies within Ukraine are noteworthy. In Dnipropetrovsk region, RR, RE, and REL systems have been determined (Bulakhov et al., 2007; Lada et al., 2009; Pysanets, 2014). It is significant that hybrid $P$. esculentus was represented by males, which was also noted in our study. By the genome size they were diploids. To the north (Poltava region), the researchers described the REL, RE, LE and RL systems. P. ridibundus prevailed among the species (Lada et al., 2011) and the REL-type prevailed among the systems there. According to our data, populations of $P$. ridibundus (RR) were widespread within Poltava region (Fig. 2) and we found here one of the rare populations of another parent species, $P$. lessonae (LL) in the eastern region. These data may indicate a high population diversity of water frogs on this territory.

The distribution and genetic structure of the green frog population systems have been described in detail in Kharkiv region, where the Siverskyi Donets River basin is the centre of genetic diversity of the $P$. esculentus complex (Biriuk et al., 2016; Shabanov et al., 2017; Shabanov et al., 2020). Pubescent $P$. lessonae were not found there. All $\mathrm{L}$ genomes are transmitted through hybrids or die at the early stages of development. RR populations and RE systems with diverse genetic structure and presence of $P$. esculentus triploid females determined by erythrocyte size were described in detail. The authors do not provide a percentage ratio, but they subdivide population systems across the regions in detail. On the border between Poltava and Kharkiv regions the REL system is indicated in the "Ruskyi Orchyk" tract, which coincides with our data. This area, which is a unique point that attracts the attention of many batrachologists, requires special monitoring studies and conservation solutions. Researchers have proposed using modelling methods to predict complex genetic processes occurring in hemiclonal population systems with interspecific hybridization and non-Mendelian inheritance (Shabanov et al., 2020).

In the north-eastern part of the range, the Eurasian water frogs form three systems of parental species (RR, LL and RL) and two mixed systems (LE and REL). Populations of $P$. ridibundus are numerically predominant and amount to $42.0 \%$ (that is almost twice less than we found), LL systems $-29.0 \%$; LE $-14.0 \%, \mathrm{REL}-11.0 \%$ and the smallest is mixed system of parental species RL $-4.0 \%$ (Svinin et al., 2013). It is interesting that the RE system has not been noted by the authors at all, although its presence is known to the east. In the Eastern European plain, all RR, LL, RE, RL, LE, REL and EE systems were detected. The predominant is the RR system - 59.6\% (Lada et al., 2011, p. 143), except the south-eastern part, where P. ridibundus is allopatric. Compared to our data, the percentage of LL populations are significantly higher $(15.4 \%)$ that is understandable for given northern area of the study. The hemiclonal RE system is less common in comparison with our data (20.0\%) and accounts to 5.9\% only. The authors noted the presence of triploids for Kharkiv, Luhansk 
and Donetsk regions that were confirmed by our data (Suriadnaia, 2015). The LE system was noted for Vinnytsia and Chernihiv regions (5.9\%). We also found it in Zhytomyr and Kyiv regions. An extremely interesting point is on the border between the forest-steppe and steppe within Kropyvnytskyi region, the Black Forest tract. Considering the ecosystem and population values, as well as the "Ruskyi Orchyk", it requires special conservation measures. The percentage of the two RL populations that we found $(2.9 \%)$ coincides with the research data, but the authors do not note it for Ukraine. The REL system occurs twice more. Researchers pointed to its distribution within Kyiv, Sumy, Poltava, Dnipropetrovsk, Kharkiv, Odesa and Kherson regions. The increase of the REL system and the decrease in the number of $P$. esculentus while moving from west to east are emphasized. The authors have an interesting opinion about the high ability of $P$. ridibundus to settle due to human introduction (Lada et al., 2011). The population system of hybridogenic $P$. esculentus of EE-type is extremely rare $(0.7 \%)$ and was noted only for Kharkiv region within Ukraine. We found it in Cherkasy region, Lyashchivka village (1.0\%). Triploidy is not proven in this population.

Six population systems have been identified within the northern margin of the range: $\mathrm{RR}-24.0 \%, \mathrm{LL}-14.0 \%$, and probably EE, LE $33.0 \%$, RE $-14.0 \%$, REL $-10.0 \%$ where $P$. esculentus reproduces through the $P$. ridibundus genome (Litvinchuk et al., 2015). LE system is the most common there that is also known in northern territories in Latvia, Estonia and Finland (Litvinchuk et al., 2015; Kulikova et al., 2017). Six population systems have been described in the Middle Volga basin: RR, LL, RL, EE, LE and REL (Borkin et al., 2002). The researchers confirmed the presence of hybrids there, emphasizing the importance of the REL population system emergence for Eastern Europe.

In Poland, as well as in other Western European parts of the range (Eastern Germany), a high percentage of triploids in all mixed populations with certain geographical distribution has been described. In particular, the percentage decreases from west to east $(7.7 \%, 6.0 \%$, and $0.2 \%)$. According to our data, the triploidy of $P$. esculentus is only $1.0 \%$. Polish researchers described population systems in detail. They identified $18 \mathrm{popu}-$ lation types, depending on genome composition, triploidy and sex structure (Rybacki \& Berger, 2001). The RE system consists of eight types and form the largest variety; the LE system has three types and these populations are the largest; the EE system has four types. If the EE systems are quite rare for our region, in the European part of the area this type is more common. The REL, LL and RR system were found only ones. In our view, the complexity in determination and classification makes impossible developing important and effective measures for the protection and conservation of valuable population complexes, although, from the view of microevolution, this should be the right approach. Most pure EE populations (7) were found in north-western Germany. One REL, four LE and two RE systems were also found there. The percentage of $P$. lessonae varied $4.0-24.0 \%$ in populations of LE and REL systems. $P$. ridibundus was observed in two populations of RE system in proportions $8.0 \%$ and $57.0 \%$; and in the single REL population (5.0\%) (Tecker et al., 2017). $P$. ridibundus prevails in all found mixed systems, but in the LE system the species ratio is almost equal for both species with the minimum prevalence of $P$. lessonae that corresponds to the studied territory within the Southern Ukraine.

In the nature conservation areas of the Middle Volga region, researchers determined six types of population systems: $41.0 \%$ RR, $25.6 \%$ LL, 7.7\% RL and LE both, 15.4\% REL and 2.6\% RE. Populations of parental species predominate, which might suggest the existence of factors impeding their successful hybridization. Among the mixed systems, REL is more common. Such a distribution may be explained by the wide distribution of $P$. ridibundus, the absence of characteristic biotopes and the significant anthropogenic impact on habitats where hybrid $P$. esculentus is usually typical (Fayzulin et al., 2018). In the western European part, within the nature protected areas of Hungary, RE and REL systems were determined. Females predominantly represent the hybrids there in contrast to our data (Herczeg et al., 2016).

The largest diversity of population systems of Southern Ukraine is found in the nature conservation areas: Dniprovsko-Orilskyi Nature Reserve, Danube Biosphere Reserve, Nyzhnodnistrovskyi, Nyzhnodniprovskyi, Oleshkivski Piski, Biloberezhzhia Sviatoslava and Buzkyi Hard
National Nature Parks, Kinburnska Kosa and Hranitno-Stepove Pobuzhzhia Regional Landscape Parks. Thus, it is necessary to create and develop the conservation areas not only for species, but also for saving the unique hemiclonal population systems having processes of hybridogenic speciation (Suriadnaia et al., 2017).

Genetic structure and ploidy. The features of genetic structure and polyploidy are important to be studied in parallel with the population systems distribution. $P$. esculentus most often clonally transfers $\mathrm{R}$ genomes in most part of the range (Plötner, 2005). Hybrids from Hungary form gametes with the clonal genome of $P$. ridibundus and produce a new hybrid generation by copulation with $P$. lessonae. The L genome may be less clonal, but has a higher level of genetic diversity than the $\mathrm{R}$ genome (Herczeg et al., 2016). REL populations are rare in Central and Eastern Europe. In Slovak populations, their hybrids form $\mathrm{R}$ gametes, and $P$. ridibundus individuals probably do not contribute to the preservation of hybridogenic lines (Mikulíček et al., 2015).

In the north-western part of the range and less frequently in Central and Eastern Europe, there are $P$. esculentus populations reproductively independent from their parent species. They are hybrid EE-type populations (Dubey et al., 2019). Their constancy is achieved because of coupling between individuals with different types of gametes. Typically, these populations include triploid individuals having two $\mathrm{L}$ genomes and one $\mathrm{R}$ genome (LLR), or two R genomes and one L (LRR). Triploid individuals were not detected in the found EE systems. Interestingly, in Southern Switzerland, a fully hybrid EE system without triploids has been reliably confirmed. The authors suggest that extraordinary plasticity of the genome elimination process is required to maintain hybrid populations without triploid individuals, namely that $P$. esculentus of both sexes must produce gametes having $\mathrm{L}$ and $\mathrm{R}$ genomes. This option can be achieved through "hybrid amphigamy". Thus, polyploidy is not the only evolutionary path for the reproductive independence of hybrids (Dubey et al., 2019). Triploid individuals of $P$. esculentus amount to $1.1 \%$ in the population (Litvinchuk et al., 2015). We described the $P$. esculentus triploids, which inhabited surroundings of the vil. Snizhkivka, Kharkiv Region (49.1522 ${ }^{\circ}$, $\left.37.2439^{\circ} \mathrm{E}\right)$ and vil. Metolkine Lugansk region $\left(48.9222^{\circ} \mathrm{N}, 38.5578^{\circ} \mathrm{E}\right)$. They amount $0.7-2.3 \%$ in the population (Suryadna, 2010; Suriadnaia, 2015). In addition, for the first time we identified an isolated island RR population with tetraploid $P$. ridibundus $(4 \mathrm{n}=52)$. According to the allozyme analysis, the percentage of triploids among different regions of Ukraine was $1.6 \%$, among hybrids $-4.0 \%$ and among parental species $0.3 \%$ (Mezhzherin et al., 2010). The majority of polyploid hybrids are identified in the Siverskyi Donets basin, one in the Lower Dnieper and one in the Volyn lakes. At the Lower Dnieper, the triploids have not yet been confirmed by us.

It should be noted that individuals with mosaics of di-, triploids and more, and aneuploid cell lines occur in population systems (Uzzel \& Berger, 1975; Ogielska et al., 2001; Suriadnaia, 2012). Populations having mosaic specimens are mostly $P$. esculentus of all mixed population systems. Along with the normal karyotype $(2 n=26)$, there are sets with different amounts of chromosomes, more often they have incomplete chromosome sets. One of the reasons for this may be the disruption of the process of genome elimination, or other mechanisms that arise under multidirectional hybridogenic speciation. Population systems where diand triploid hybrid frogs coexist with parental species (RE system) are found in Central Europe and in Eastern Ukraine, including our data.

The results of quantitative karyological analysis of diploid and triploid hybrides crossing in the RE system showed that $3 n$ hybrids can transmit the genes of the parent species they coexist with, by producing haploid gametes (13 bivalents) with the same genome composition. Triploid hybrids cannot produce $3 \mathrm{n}$ individuals by crossing between themselves and depend on diploid hybrid females, which produce diploid female gametes (26 bivalents). In other population systems, most diploid and triploid hybrid females may unexpectedly produce gametes with the genome of the parental species. Based on these data, it is logical to assume that in the allmales RE system in the south of Ukraine, triploids are absent or extremely rare. Nevertheless, aneuploidy occurs in this case. This may explain the predominant presence of triploids exactly in the north-western part of the range and in the LE system too (Rybacki \& Berger, 2001). Hybrids have many roots of origin and include a wide variety of parental genomes. 
Fully hybrid populations are proposed to be considered as evolutionary units on the path to hybrid speciation. Support of such populations requires constant genome exchange between diploids and triploids (Hoffmann et al., 2015), but other alternative scenarios that we have already noted are possible.

Another study deserves attention considering the high prevalence of RR populations. Today we have an ambiguous systematic status of $P$. ridibundus in Southern Ukraine, particularly in the Crimea, according to the analysis of mitochondrial and nuclear DNA. We are talking about the presence of two genetically differentiated forms: "Western" (= Central European P. ridibundus) and "Eastern" (= Anatolian P. cf. bedriagae). Alleles of the "Western" form are less common than the "Eastern" ones. In the formation of hybridogenic P. esculentus, the "Western" form of the marsh frog plays a major role (Fayzulin et al., 2017) and only 4\% comes from $P$. cf. bedriagae. We do not deliberately touch on the production of gametes, introgression, genome composition and genetic structure in this work, since this issue has not yet been studied for the south of continental Ukraine. Nevertheless, it is extremely important and relevant especially in view of the strategy and mechanisms of different surviving taxa, which coexist and form mixed semi-clonal or non-clonal population systems.

Sex structure of mixed population systems. Hybrid P. esculentus in mixed systems may be unisexual or represented by both sexes (Gunther, 1975). Unisexual populations (EE) have been found in Latvia and other parts of the range (Saune \& Borkin, 1993). According to our results, almost all of $P$. esculentus RE systems of the Southern Ukraine are allmales and have reproductive anomalies. Males in some populations of the north-eastern part of the range are also identified with reduced gonads (54\%) (Svinin et al., 2013). Gonad abnormalities in P. esculentus are described for Eastern Europe and represent $61 \%$. It was determined that its number significantly affects the hybridization (Litvinchuk, 2018).

Genetic basis of the male-represented RE system sex composition was studied in detail for the upper Oder, Germany (Dolezalkovâ-Kastankovâ et al., 2018). The RE $\hat{\jmath}$ system is of high interest in its evolutionary relationships, which may be also relevant for the south of Ukraine. The mechanism of the male system self-maintenance is still unclear. As a rule, hybrids clonally transmit the maternal genome. Hybridity is restored in each generation by parental species insemination, whose genome has been excluded from the germline of the hybrid. RE systems were described from different parts of the distribution range and, unlike the LE system, some $P$. esculentus males transmit only the lessonae genome, others - only ridibundus, and some males produce both ridibundus and lessonae gametes. According to artificial crosses between $P$. ridibundus females and $P$. esculentus males, there are usually two genotypes: if the ridibundus egg (R-egg) is fertilized by sperm with the $\mathrm{R}$ genome, $\mathrm{RR}$ females are formed, while combinations of the R-egg and L-sperm produce only hybrid males $\left(\mathrm{LR}^{\top}\right)$. This potentially explains the conservation of the male line in natural populations. Males of $P$. esculentus actively support their exclusively male hybrid line. Therefore, hybridogenesis combines both elements of clonal and sexual reproduction, which is the most promising reproductive way of male unisexuality maintenance in hybrids. Moreover, the clonal genome of lessonae contains in the exclusively male $P$. esculentus line and plays a key role in the formation of these processes (Dolezalkovâ-Kastankovâ et al., 2018). We can predict that populations of Southern Ukraine may have other mechanisms for the unisexuality evolution and parental species conservation. We do not exclude that the hypothesis about the ancient origin of the $P$. lessonae genome may "work" in this case too. The south of Ukraine can be considered as a model territory since it is likely that the locality of the populations of $P$. esculentus and the parent $P$. lessonae outside the main range, may retain a unique relict genetic diversity of the studied groups unlike Central European populations. Definitely, conservation of these species with their complex evolutionary relationships requires a comprehensive approach with special protective measures for the unique population systems of the Eurasian water frogs of Southern Ukraine.

\section{Conclusions}

Three population systems for the Southern Ukraine were identified and confirmed: $76.2 \%$ of them are RR, $20.0 \%$ RE and $3.8 \%$ REL. These and four other population systems are distributed northwards within the main range of $P$. lessonae and $P$. esculentus, where their ratios are: RR $75.0 \%, \mathrm{RE}-8.8 \%$, REL, LL and RL $-2.9 \%$ both, LE $-5.9 \%$ and EE $1.4 \%$. In all mixed systems $P$. ridibundus prevails. In the LE system, the species ratio is almost the same, with a small advantage of $P$. lessonae. Populations, in which polyploids and aneuploids presented, range 0.7 $2.3 \%$. The triploids of $P$. esculentus $(3 \mathrm{n}=39)$ were confirmed in the RE system of the Siverskyi Donets basin and the tetraploid of $P$. ridibundus $(4 n=52)$ in the isolated RR system of the Dnipro basin population. There is a different gender ratio among population systems: in $\mathrm{RR}-1.0: 1.0$

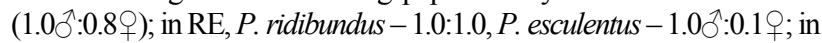
REL, P. ridibundus $-1.0{ }^{\AA}: 1.0$, $P$. esculentus $1.00^{\top}: 0.2 \bigcirc$ and $P$. lessonae $-0.4{ }^{\top}: 1.0$ 우.

$P$. ridibundus abundance in RR and RE systems averages 5-35 indiv./100 $\mathrm{m}$ and tends to decrease. The number of $P$. esculentus is about $2-$ 9 indiv. $/ 100 \mathrm{~m}$. The number of $P$. lessonae in the REL system is low. The RR-type occupies a wide range of freshwater bodies, including synanthropic ecosystems. RE and REL are typical for floodplain willow and poplar forests. Hydrochemical and hydrophysical indices of biotopes indicate optimal conditions for the studied species. The average air temperature for all systems is $18.0^{\circ} \mathrm{C}$ ( $\left.\min -\max : 7.0-27.0\right)$, water $-18.0^{\circ} \mathrm{C}(5.2-$ $30.0)$; salts content of $2.0 \% \mathrm{o}(0.5-6.8)$; $\mathrm{pH} 8.4(6.1-10.0)$.

Southern Ukraine may become a model territory, as probably the locality of $P$. esculentus populations and the native $P$. lessonae species may retain the unique relict genetic diversity of the studied groups. We can assume that populations in the south of Ukraine may have their own mechanisms for the evolution of unisexual hybrids and for the conservation of parental species. Biotopic preferences, endurance limits, ratios and numbers of taxa are critical to adequate assessment of biological (taxonomic) diversity and development of an appropriate strategy for population systems conservation.

We are sincerely grateful to Dr. Igor Zagorodniuk for valuable advice and critical remarks and to Dr. Spartak Litvinchuk for his support and valuable recommendations, which greatly improved the manuscript. We are especially grateful to the anonymous reviewers for their important comments. We would like to express our thankfulness to Olga Manuilova and Viktor Radchenko for support of the study. With gratitude, we remember Prof. Yevgen Pysanets, the founder and first President of the Ukrainian Herpetological Society.

The work was partially supported by the Joint Herpetological Research Micro-Grant "Ecological and genetic structure of Pelophylax esculentus complex populations: Stability and variability in conditions of natural and anthropogenic transformation of ecosystems" (JHR/2018/02/LV-UA/PelEsc-01). Our recent research was also supported by IDEA WILD (http://ideawild.org).

\section{References}

Avise, J. C. (2008). Clonality: The genetics, ecology, and evolution of sexual abstinence in vertebrate animal. Oxford Scholarship Online, New-York.

Berger, L. (1983). Western Palearctic water frogs (Amphibia, Ranidae): Systematics, genetics and population compositions. Experientia, 39(2), 127-130.

Berger, L., \& Berger, W. A. (1994). Persistence of all-hybrid water frog populations (Rana kl. esculenta) in Northern Germany. Genetica Polonica, 35, 73-80.

Biriuk, O. V., Shabanov, D. A., Korshunov, A. V., Borkin, L. J., Lada, G. A., Pasynkova, R. A., Rosanov, J. M., \& Litvinchuk, S. N. (2016). Gamete production patterns and mating systems in water frogs of the hybridogenetic Pelophylax esculentus complex in North-Eastern Ukraine. Journal of Zoological Systematics and Evolutionary Research, 54(3), 215-225.

Borkin, L. J., Bezman-Moseiko, O. S., Mazepa, G. A., Zinenko, A. I., Korshunov, A. V., Lada, G. A., Shabanov, D. A., Litvinchuk, S. N., \& Rozanov, J. M. (2008). O yuzhnoy granitse rasprostraneniya gibridnoy Rana esculenta (Ranidae, Anura, Amphibia) na territorii Ukrainy i Moldovy: Dannyye protochnoy DNK-tsitometrii [On the southern limit of range of hybrid Rana esculenta (Ranidae, Anura, Amphibia) in Ukraine and Moldova: DNA flow cytometry evidence]. Proceeding of the Ukranian Herpetological Society, 1, 5-10 (in Russian).

Borkin, L. J., Korshunov, A. V., Lada, G. A., Litvinchuk, S. N., Rosanov, J. M., Shabanov, D. A., \& Zinenko, A. I. (2004). Mass occurrence of polyploid green frogs (Rana esculenta complex) in Eastern Ukraine. Russian Journal of Herpetology, 11(3), 194-213. 
Borkin, L. J., Litvinchuk, S. N., Mannapova, E. I., Pestov, M. V., \& Rosanov, J. M. (2002). The distribution of green frogs (Rana esculenta complex) in Nizhny Novgorod province, Central European Russia. Russian Journal of Herpetology, 9(3), 195-208.

Borkin, L. J., Litvinchuk, S. N., Rosanov, J. M., \& Milto, K. D. (2001). Cryptic speciation in Pelobates fuscus (Anura, Pelobatidae): Evidence from DNA flow cytometry. Amphibia-Reptilia, 22(4), 387-396.

Bulakhov, V. L., Gasso, V. Y., \& Pakhomov, A. Y. (2007). Biolohichne riznomanittia Ukrainy. Dnipropetrovska oblast. Zemnovodni ta plazuny [Biological diversity of Ukraine. The Dnipropetrovsk region. Amphibians and reptiles (Amphibia et Reptilia)]. Dnipropetrovsk National University, Dnipropetrovsk (in Ukrainian)

Caune, I. A., \& Borkin, L. J. (1993). Novyj variant odnopolo-biseksual'nych populjacionnych sistem u Evropejskich zelenych ljagusek (Rana esculenta complex) [A new kind of unisexual-bisexual population system in European green frogs (Rana esculenta complex)]. In: Gibridizacija i problema vida u pozvonocnych. Sbornik Trudov Zoologiceskogo Muzeja MGU, Moscow. Pp. 34-52.

Christiansen, D. G., Jakob, C., Arioli, M., Roethlisberger, S., \& Reyer, H.-U. (2010) Coexistence of diploid and triploid hybrid water frogs: Population differences persist in the apparent absence of differential survival. BMC Ecology, 10, 14.

Christiansen, D., Fog, G. K., Pedersen, B. V., \& Boomsma, J. J. (2005). Reproduction and hybrid load in all-hybrid populations of Rana esculenta water frogs in Denmark. Evolution, 59(6), 1348-1361.

Dedukh, D., Litvinchuk, S., Rosanov, J., Shabanov, D., \& Krasikova, A. (2017). Mutual maintenance of di- and triploid Pelophylax esculentus hybrids in R-E systems: Results from artificial crossings experiments. BMC Evolutionary Biology, 17, 220.

Doležálková-Kaštánková, M., Pruvost, N. B. M., Plötner, J., Reyer, H.-U., Janko, K. \& Choleva, L. (2018). All-male hybrids of a tetrapod Pelophylax esculentus share its origin and genetics of maintenance. Biology of Sex Differences, 9, 13.

Dubey, S., Maddalena, T., Bonny, L., Jeffries, D. L., \& Dufresnes, C. (2019). Population genomics of an exceptional hybridogenetic system of Pelophylax water frogs. BMC Evolutionary Biology, 19, 164

Ebendal, T. (1979). Distribution, morphology and taxonomy of the Swedish green frogs (Rana esculenta complex). Mitteilungen aus dem Zoologischen $\mathrm{Mu}$ seum in Berlin, 55(1), 143-152.

Faizulin, A. I., Lada, G. A., Litvinchuk, S. N., Korzikov, V. A., Svinin, A. O. Zaks, M. M., Rosanov, Y. M., Kuzovenko, A. E., Zamaletdinov, R. I., \& Ermakov, O. A. (2017). O rasprostranenii syedobnoy lyagushki Pelophylax esculentus (Linnaeus. 1758) na territorii Volzhskogo basseyna [On distribution of the edible frog Pelophylax esculentus (Linnaeus, 1758) on the territory of the Volga river drainage]. Tambov University Reports, Series Natural and Technical Sciences, 22(5), 809-817 (in Russian).

Fayzulin, A. I., Zamaletdinov, R. I., Litvinchuk, S. N., Rosanov, J. M., Borkin, L. J., Ermakov, O. A., Ruchin, A. B., Lada, G. A., Svinin, A. O., Bashinsky, I. V., \& Chikhlyaev, I. V. (2018). Vidovoy sostav i osobennosti rasprostraneniya zelenykh lyagushek (Pelophylax esculentus complex) na osobo okhranyayemykh prirodnykh territoriyakh Srednego Povolzhia (Rossiya) [Species composition and distributional peculiarities of green frogs (Pelophylax esculentus complex) in protected areas of the middle Volga region (Russia)]. Nature Conservation Research, 3(1), 1-16 (in Russian).

Günther, R. (1975). Untersuchungen der Meiose bei Männchen von Rana ridibunda Pall., Rana lessonae Cam. und deren Bastardform "Rana esculenta" L. (Anura) [Studies of meiosis in males of Rana ridibunda Pall., Rana lessonae Cam. and their hybrid "Rana esculenta" L. (Anura)]. Biologisches Zentralblatt, 94(3), 277-294 (in German).

Herczeg, D., Vörös, J., Christiansen, D. G., Benovics, M., \& Mikulíček, P. (2016). Taxonomic composition and ploidy level among European water frogs (Anura: Ranidae: Pelophylax) in Eastern Hungary. Journal of Zoological Systematics and Evolutionary Research, 55(2), 129-137.

Hoffmann, A., Plötner, J., Pruvost, N. B. M., Christiansen, D. G., Röthlisberge, S. Choleva, L., Mikulíček, P., Cogălniceanu, D., Sas-Kovács, I., Shabanov, D., Morozov-Leonov, S., \& Reyer, H.-U. (2015). Genetic diversity and distribution patterns of diploid and polyploid hybrid water frog populations (Pelophylax esculentus complex) across Europe. Molecular Ecology, 24(17), 4371-4391.

Kulikova, E. A., Kolenda, K., Ceirans, A., Pupin, M., Pupina, A., \& Ogielska, M (2017). Pervyye rezultaty vidovoy diagnostiki zelenykh lyagushek (Pelophylax esculentus complex) $\mathrm{v}$ Latvii [First results of species diagnostics of green frogs (Pelophylax esculentus complex) in Latvia]. In: Zoological Readings 2017: Proceedings of the International Scientific and Practical Conference (Grodno, March 15-17, 2017). Yanka Kupala State University of Grodno, Grodno. 118-119 (in Russian).

Kuzemko, A. A., Didukh, Y. P., Onyshchenko, V. A., Borsukevych, L. M., Chorney, I. I., Moysiyenko, I. I., Sadogurska, S. S., Kish, R. Y., Pashkevych, N. A., Khodosovtsev, O. Y., Iakushenko, D. M., Vynokurov, D. S., Dziuba, T. P., Iemelianova, S. M., Fitsailo, T. V., Bashta, A.-T. V., Budzhak, V. V., Vashenyak, Y. A., Zakharova, M. Y., Kovtoniuk, A. I., Kolomiichuk, V. P., Sadova, O. F. Ralo, V. M., Tsarenko, P. M., Tokariuk, A. I., \& Shapoval, V. V. (2018). In:
Kuzemko, A. A., Didukh, Y. P., Onyshchenko, V. A., \& Sheffer, Y. (Eds.). Natsionalnyi kataloh biotopiv Ukrainy [National habitat catalogue of Ukraine] Natural Person-Entrepreneur Klymenko, Y. A., Kyiv (in Ukrainian).

Lada, G. A., Borkin, L. J., \& Vinogradov, A. E. (1995). Distribution, population systems and reproductive behaviour of green frogs (hybridogenetic Rana esculenta complex) in the Central Chernozem Territory of Russia. Russian Journal of Herpetology, 2(1), 46- 47.

Lada, G. A., Borkin, L. J., Litvinchuk, S. N., \& Rosanov, J. M. (2009). Vidovoy sostav zelenykh lyagushek Rana esculenta complex (Amphibia, Ranidae) Dnepropetrovskoy oblasti (Vostochnaya Ukraina) [Green frog Rana esculenta complex (Amphibia, Ranidae) composition in Dnepropetrovsk Province (Eastern Ukraine)]. Proceeding of the Ukranian Herpetological Society, 2, 37-44 (in Russian).

Lada, G. A., Borkin, L. J., Litvinchuk, S. N., \& Rosanov, J. M. (2011). Vidovoy sostav i populyatsionnyye sistemy zelenykh lyagushek Rana esculenta complex (Amphibia, Anura) baseyna r. Psel [Species composition and population systems of green frogs, Rana esculenta complex (Amphibia, Anura) in the Psyol' River drainage]. Proceeding of the Ukranian Herpetological Society, 3, 76-83 (in Russian)

Lada, G. A., Gordeev, D. A., Prilipko, S. K., Borkin, L. Y., Litvinchuk, S. N., \& Rosanov, Y. M. (2016). O yuzhnoy granitse areala prudovoy lyagushki Pelophylax lessonae (Camerano, 1882): Dostovernoye obnaruzheniye vida v Volgogradskoy oblasti [On the southem distributional limit of the pool frog Pelophylax lessonae (Camerano, 1882): The first record in Volgograd region, Russia]. Biological Communications, 3, 64-68 (in Russian)

Litvinchuk, S. N. (2018). Testicular anomalies in the hybridogenetic frog Pelophylax esculentus (Amphibia: Anura: Ranidae). In: The Second International conference "Amphibian and reptiles anomalies and pathology: Methodology, evolutionary significance, monitoring and environmental health", KnE Life Sciences, 92-96.

Litvinchuk, S. N., Borkin, L. J., Litvinchuk, Y. S., \& Rosanov, J. M. (2015). Distribution and population systems of green frogs (Pelophylax esculentus complex) in Kaliningrad oblast', Russia (Baltic Sea region). Russian Journal of Herpetology, 22(3), 188-196.

Mallet, J. (2005). Hybridization as an invasion of genome. Trends in Ecology and Evolution, 20(5), 229-237.

Mezhzherin, S. V., Morozov-Leonov, S. Y., Rostovskaya, O. V., Shabanov, D. A., \& Sobolenko, L. Y. (2010). Ploidnost i geneticheskaya struktura gibridnykh populyatsiy vodnykh lyagushek Pelophylax esculentus (L., 1758) complex (Amphibia. Ranidae) Ukrainy [Ploidy and genetic structure of hybrid populations of water frogs Rana esculentus complex (Amphibia, Ranidae) of Ukraine fauna]. Cytology and Genetics, 44(4), 23-28 (in Russian).

Mikitinez, G. I., \& Suryadna, N. M. (2007). Rozpovsiudzhennia ta morfolohichni osoblyvosti zelenykh zhab ponyzzia Dnipra [Distribution and morphological characteristics of green frogs of the lower Dnepr]. Scientific Bulletin of the Uzhhorod University, Series Biology, 21, 85-91 (in Ukrainian).

Mikulíček, P., \& Kotlík, P. (2001). Two water frog populations from Western Slovakia consisting of diploid females and diploid and triploid males of the hybridogenetic hybrid Rana esculenta (Anura, Ranidae). Zoosystematics and Evolution, 77(1), 59-64.

Mikulíček, P., Kautman, M., Kautman, J., \& Pruvost, N. B. M. (2015). Mode of hybridogenesis and habitat preferences influence population composition of water frogs (Pelophylax esculentus complex, Anura: Ranidae) in a region of sympatric occurrence (Western Slovakia). Journal of Zoological Systematics and Evolutionary Research, 53(2), 124-132.

Ogielska, M., Kazana, K., \& Kierzkowski, P. (2001). DNA content in erythrocyte nuclei of water frogs from a pure Rana esculenta population in Dêbki (Gdansk district, Poland). Mitteilungen aus dem Zoologischen Museum in Berlin, 77(1), 65-70.

Plötner, J. (2005). Die Westpalaarktichen Wasserfrosche. Laurenti-Verlag, Bielefeld.

Pruvost, N. B. M., Hoffmann, A., \& Reyer, H.-U. (2013). Gamete production patterns, ploidy, and population genetics reveal evolutionary significant units in hybrid water frogs (Pelophylax esculentus). Ecology and Evolution, 3(9), 2933-2946.

Pysanets, Y. (2014). Zemnovodni Skhidnoi Yevropy. Chastyna 2. Riad Bezkhvost [Amphibians of Eastern Europe. Part 2. Order Ecaudata]. Zoological Museum NNPM NAS Ukraine, Kyiv (in Ukrainian).

Pysanets, Y. M., \& Suriadna, N. M. (2007). Herpetolohichni doslidzhennia (zemnovodni ta plazuny) [Herpetological studies (amphibians and reptiles)]. In: Siokhin, V. D. (Ed.). Metodyky inventaryzatsii ta otsinky suchasnoho stanu bioriznomanittia pryrodnykh kompleksiv ta landshaftiv, neobkhidnykh dlia formuvannia rehionalnykh ekolohichnykh merezh [Methods for inventorying and evaluation the current state of biodiversity of natural complexes and landscapes needed to form regional ecological networks]. Branta, Melitopol. Pp. 41-60 (in Ukrainian).

Rybacki, M., \& Berger, L. (2001). Types of water frog populations (Rana esculenta complex) in Poland. Zoosystematics and Evolution, 77(1), 51-57.

Shabanov, D. A., Biriuk, O. V., Korshunov, O. V., \& Kravchenko, M. O. (2017) Poshyrennia riznykh typiv hemiklonalnykh populiatsiinykh system hibrydo- 
hennoho kompleksu zelenykh zhab (Pelophylax esculentus complex) [Distribution of different types of hemiclonal population systems of the hybrid frog (Pelophylax esculentus complex)]. Conservation Biology in Ukraine, 5, 141-146 (in Ukrainian).

Shabanov, D., Vladymyrova, M., Leonov, A., Biriuk, O., Kravchenko, M., Mair, Q., Meleshko, O., Newman, J., Usova, O., \& Zholtkevych, G. (2020). Simulation as a method for asymptotic system behavior identification (e.g. water frog hemiclonal population systems). Springer Nature Switzerland AG 2020. ICTERI 2019, CCIS 1175. Pp. 392-414.

Suriadna, N. M., \& Pysanets, Y. M. (2010). Zemnovodni (Amphibia: Caudata, Anura) [Amphibians (Amphibia: Caudata, Anura)]. Catalogue of collections, Part, 1. MMD Publishing House LLC, Melitopol (in Ukrainian).

Suriadna, N. N., Karmyshev, Y. V., Mikitinets, G. I., \& Manuilova, O. N. (2017). Puti minimizatsii vliyaniya antropogennykh faktorov na batrakhogerpetofaunu stepnykh Natsionalnykh prirodnykh parkov Ukrainy [Ways of minimizing influence of anthropogenic factors on batracho-herpetofauna of steppe national natural parks of Ukraine]. Topical Problems of Zoological Science in Belarus: Collection of Articles XI of the Zoological International Scientific and Practical Conference, dedicated to the decade of foundation of the Scientific-Production Center of the National Academy of Sciences of Belarus on Bioresources, Belarus, Minsk, November 1-3, 2017. Publisher A. N. Varaksin, Minsk. Pp. 382-387 (in Russian).

Suriadna, N., \& Mykytynets, G. (2019). Pro melitopolski kolektsii zemnovodnykh i plazuniv [On the Melitopol collections of amphibians and reptiles]. Zagorodniuk, I. (Ed.). Natural History Museology. Natural History Museums in Ukraine: Formation and Prospects for Development. NAS of Ukraine; National Museum of Natural History, Kyiv. Vol. 5, 225-227 (in Ukrainian).

Suriadnaia, N. N. (2015). Morfologiya khromosom triploidnykh Pelophylax esculentus (Linnaeus, 1758) Ukrainy [The morphology of the chromosomes of triploid Pelophylax esculentus (Anura, Ranidae) of Ukraine]. Zbirnyk Prac' Zoologičnogo Muzeû, 46, 85-95 (in Russian).

Suryadna, N. M., \& Mikitinez, G. I. (2008). Poperedni dani z rozpovsiudzhennia hibrydohennoho taksonu (Pelophylax esculentus Linnaeus, 1758) na pivdni Ukrainy [Preliminary data on expansion of the hybridogenic taxon (Pelophylax esculentus Linnaeus, 1758) in Southern Ukraine]. Proceeding of the Ukranian Herpetological Society, 1, 99-104 (in Ukrainian).
Suryadna, N. N. (2003). Materialy po kariologii zelenykh lyagushek (Rana ridibunda Pallas, 1771; Rana lessonae Camerano, 1882; Rana esculenta Linnaeus, 1758) s territorii Ukrainy [The data on caryology of green frogs (Rana ridibunda, $R$. lessonae, $R$. esculenta) from Ukraine]. Vestnik Zoologii, 37(1), 33-40 (in Russian).

Suryadna, N. N. (2010). Novyie nahodki triploidov Pelophylax esculentus (Linnaeus, 1758) na vostoke Ukrainy [New records of triploid Pelophylax esculentus (Linnaeus, 1758) in Eastern Ukraine]. Current Studies in Herpetology, 10(3-4), 128-131 (in Russian).

Suryadna, N. N. (2012). Hromosomnye abberacii amfibij, kak ocenochnyj indikator stabil'nosti razvitiya [Chromosomal aberrations of amphibians as an evaluation indicator of developmental stability]. The Problems of Herpetology. Proceedings of the 5th Congress of the Alexander M. Nikolsky Herpetological Society 24-27 September 2012 Minsk, Belarus. Scientific and Practical Center of the National Academy of Sciences of Belarus on Bioresources, Minsk. Pp. 305-309 (in Russian).

Suryadnaya, N. N. (2004). Meiotychni khromosomy Rana esculenta kompleksa z terytorii Ukrainy [Meiotic chromosomes of green frogs (Rana esculenta complex) of the Ukraine territory]. Cytology and Genetics, 38(6), 28 -32 (in Ukrainian).

Svinin, A. O., Litvinchuck, S. N., Borkin, L. J., \& Rosanov, J. M. (2013). Rasprostraneniye i tipy populyatsionnykh sistem zelenykh lyagushek roda Pelophylax Fitzinger, 1843 v Respublike Mariy El [Distribution and population system types of green frogs (Pelophylax Fitzinger, 1843) in Mari El republic]. Current Studies in Herpetology, 13(3-4), 137-147 (in Russian).

Tecker, A., Göcking, C., Menke, N., Schreiber, R., \& Plötner, J. (2017). Neue Daten zur Morphologie, Genetik und Verbreitung der Wasserfrösche (Pelophylax spp.) im Münsterland (NRW) unter besonderer Berücksichtigung des Kleinen Wasserfroschs (Pelophylax lessonae) [New data on morphology, genetics, and distribution of water frogs (Pelophylax spp.) in the Münsterland with particular focus on the pool frog (Pelophylax lessonae)]. Zeitschrift für Feldherpetologie, 24, 19-44 (in German).

Uzzell, T., \& Berger, L. (1975). Electrophoretic phenotypes of Rana ridibunda, Rana lessonae, and their hybridogenetic associate, Rana esculenta. Proceedings of the Academy of Natural Sciences of Philadelphia, 127(25), 13-24. 